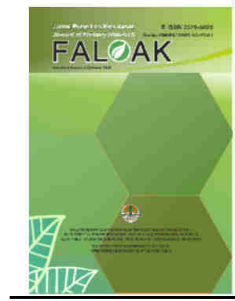

Jurnal Penelitian Kehutanan Faloak (2021) 5(1), 47-61

JURNAL PENELITIAN KEHUTANAN FALOAK

Akreditasi KEMENRISTEKDIKTI: 10/E/KPT/2019

http://ejournal.forda-mof.org/ejournal-litbang/index.php/JPKF

\title{
JENIS LEBAH MADU DAN TANAMAN SUMBER PAKAN PADA BUDI DAYA LEBAH MADU DI HUTAN PRODUKSI SUBANJERIJI, KABUPATEN MUARA ENIM, SUMATERA SELATAN
}

\section{(Honeybee diversity and woof source of beekeeping in Subanjeriji production forest, Muara Enim District, South Sumatera)}

\author{
Beni Rahmad ${ }^{1}$, Nurhayati Damiri ${ }^{*}$, dan Mulawarman ${ }^{1}$ \\ ${ }^{1}$ Program Pasca Sarjana, Universitas Sriwijaya Palembang \\ J1. Padang Selasa No. 524, Kota Palembang, Sumatera Selatan 30139
}

\begin{abstract}
The objective of this research was to identify Honeybee's diversity, plants as a potential woof source, and the participation of Forest Farmers Group (KTH) Sari Puspa members in the Subanjeriji Production Forest, Muara Enim District, Sumatera Selatan Province. Identification of bees was carried out by collecting samples which are then identified based on the species key determination. Collecting the potential woof source employed the transect method established around the beekeeping sites. Direct observation and interviews with beekeeper samples were utilized to determine community participation in forest conservation efforts to support beekeeping. The results indicated that it has been identified in field the sting bee of Apis cerana Fabr and stingless bee of Trigona, with variations of as many as six species: Genitrigona thoracica, Heterotrigona itama, Tetrigona apicalis, Lepidotrigona terminata, Tetragonula testaceitarsis, and Tetragonula laeviceps. The types of potential bee woof sources that have been identified consist of forestry plants namely Acacia mangium, Multi-Purpose Tree Species (MPTS) such as rubber (Hevea brasiliensis) and fruit-producing plants, and shrubs. Most of the honey beekeepers understand that forest plants' existence is beneficial to support honey production so that the majority of farmers are involved in land enrichment efforts with woody plants and MPTS that produce fruit.
\end{abstract}

Keywords: Honeybee, Woof source, Participation, Subanjeriji

\section{ABSTRAK}

Penelitian ini bertujuan untuk mengidentifikasi jenis lebah madu dan sumber pakan potensial, serta mengetahui tingkat partisipasi anggota Kelompok Tani Hutan (KTH) Sari Puspa dalam usaha pelestarian kawasan hutan di Hutan Produksi Subanjeriji, Kabupaten Muara Enim, Provinsi Sumatera Selatan. Identifikasi jenis lebah dilakukan dengan pengumpulan sampel lebah yang selanjutnya diidentifikasi berdasarkan kunci determinasi. Pengumpulan data tanaman pakan potensial dilakukan dengan metode transek yang dibuat di sekitar lokasi budi daya lebah. Analisis tingkat partisipasi masyarakat dalam usaha pelestarian hutan dilakukan dengan metode wawancara dan pengamatan secara lansung ke lokasi penelitian. Lokasi pengambilan data dilakukan pada 3 desa yang terletak di dalam kawasan hutan, berbatasan dengan kawasan hutan dan di luar kawasan hutan. Hasil penelitian menunjukkan bahwa jenis lebah madu yang dibudidayakan terdiri atas jenis lebah bersengat dari spesies Apis cerana Fabr. dan jenis lebah kelulut sebanyak 6 spesies yakni Genitrigona thoracica, Heterotrigona itama, Tetrigona apicalis, Lepidotrigona terminata, Tetragonula testaceitarsis, dan Tetragonula laeviceps. Jenis tanaman sumber pakan lebah potensial yang berhasil diidentifikasi terdiri atas jenis tanaman kehutanan yaitu akasia (Acacia mangium), tanaman multi guna/Multi Purpose Tree Species (MPTS) seperti karet (Hevea brasiliensis) dan tanaman penghasil buah, tanaman perdu dan semak. Sebagian besar pembudi daya memahami bahwa keberadaan tanaman hutan sangat bermanfaat untuk mendukung produksi madu, sehingga mayoritas pembudi daya terlibat dalam upaya pengayaan lahan dengan tanaman berkayu dan tanaman jenis MPTS yang menghasilkan buah-buahan.

Kata kunci: Lebah Madu, Tanaman Pakan, Partisipasi, Subanjeriji

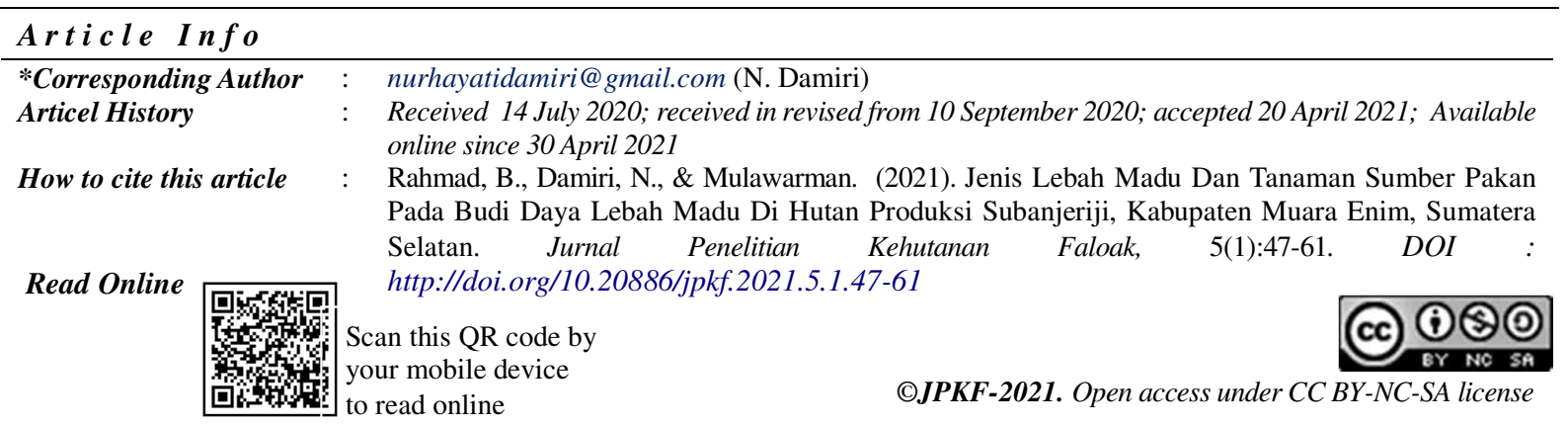




\section{PENDAHULUAN}

Budi daya lebah madu merupakan salah satu usaha yang memiliki prospek cukup baik. Keadaan alam Indonesia dengan luas hutan sekitar 143 juta hektar sangat cocok untuk usaha budi daya lebah karena Indonesia kaya akan ragam tanaman berbunga sebagai sumber pakan lebah. Kenyataan ini memungkinkan produksi madu di Indonesia dapat terjadi sepanjang tahun (Novandra \& Widnyana, 2013). Usaha budi daya lebah madu dapat menjadi alternatif tambahan penghasilan bagi masyarakat sekitar kawasan hutan, karena tidak membutuhkan biaya pengadaan pakan (zero feed cost), serta madu dapat dipanen satu kali dalam 2 minggu atau setara dengan tujuh bulan dalam setahun (Sihombing, 2005). Sebagai perbandingan, jika pembudi daya memiliki 100 kotak budi daya (stup), maka dalam satu musim produktif akan mampu menghasilkan tiga sampai empat ton madu per tahun.

Pemahaman jenis lebah dalam usaha budi daya lebah madu sangat penting, salah satunya adalah berhubungan dengan preferensi jenis pakan dan produk yang dihasilkan. Lebah sosial (social bees) dibedakan dari lebah soliter (solitary bees) karena memiliki kehidupan sosial berupa pembagian tugas dalam kasta-kasta. Lebah sosial dikelompokkan dalam tiga subfamili yaitu Apinae, Melliponinae dan Bombicinae (Michener, 2007). Lebah sosial merupakan penyerbuk potensial yang memiliki peran penting dalam regenerasi tumbuhan hutan dan tanaman pertanian. Kehidupan lebah sosial sangat bergantung pada sumber pakan dari tumbuhan alami, liar dan tanaman budi daya (Kahono \& Erniwati, 2014). Lebah sosial memiliki sebaran horizontal dan vertikal yang terbatas. Keberadaan suatu spesies lebah sosial sangat berhubungan dengan kecocokan pada habitat persarangan dan sumber pakannya (Roubik, 1991).
Pakan merupakan kebutuhan yang sangat penting bagi keberlanjutan budi daya lebah madu. Kekurangan pakan menjadi masalah yang sangat serius dan dapat menghambat perkembangan usaha budi daya lebah madu yang akan berdampak pada penurunan produksi madu, polen lebah dan royal jelly. Pada akhirnya hal ini akan menurunkan pendapatan pembudi daya lebah. Kekurangan pakan juga dapat memengaruhi koloni lebah, di antaranya adalah jumlah lebah pekerja sedikit, produksi madu, polen lebah dan royal jelly yang rendah, produktivitas lebah ratu menurun karena kurangnya pasokan pakan nektar dan polen sebagai sumber karbohidrat dan protein (Agussalim et al., 2017).

Usaha budi daya lebah menghasilkan produk perlebahan di antaranya adalah madu, royal jelly, polen lebah (bee pollen), lilin, perekat (propolis), dan racun lebah. Produkproduk lebah madu ini mempunyai nilai ekonomi yang sangat tinggi, yang dapat meningkatkan upaya pemenuhan gizi masyarakat dan dapat menjadi pendapatan tambahan pembudi daya lebah. Manfaat tidak langsung (indirect benefits) budi daya lebah antara lain adalah berkaitan dengan proses pelestarian lingkungan dan sumber daya hutan, peningkatan produktivitas tanaman, dan adanya hubungan simbiosis yang saling menguntungkan. Tanaman yang berada di hutan, kawasan perkebunan atau area pertanian akan menjadi penghasil nektar dan tepung sari melalui bagian bunga tanaman yang dimanfaatkan sebagai pakan oleh lebah, sementara lebah madu akan membantu proses penyerbukan bunga tanaman (Saepudin et al., 2017).

Salah satu kawasan hutan yang mempunyai peran dalam budi daya lebah masyarakat sekitarnya adalah Hutan Produksi Subanjeriji. Hutan produksi ini terletak di 
Kabupaten Muara Enim, Provinsi Sumatera Selatan yang izin konsesinya dimiliki oleh PT. Musi Hutan Persada (MHP) yang bergerak dalam usaha budi daya tanaman akasia (Acacia mangium) sebagai bahan baku pembuatan bubur kertas (pulp). Program pemberdayaan masyarakat melalui kegiatan budi daya lebah madu telah dilakukan dengan tujuan untuk menekan laju degradasi dan alih fungsi lahan pada kawasan hutan. Namun demikian upaya ini memerlukan dukungan agar tingkat partisipasi masyarakat dalam pelestarian hutan semakin meningkat. Salah satu dukungan yang diperlukan adalah pengetahuan jenis lebah yang dibudidayakan, sumber pakan potensial dan partisipasi masyarakat saat ini. Oleh sebab itu, tujuan penelitian ini adalah mengidentifikasi jenis lebah madu, pakan potensial lebah madu dan partisipasi pembudi daya dalam upaya pengayaan tanaman pakan lebah sebagai bagian dari usaha pelestarian hutan di sekitar kawasan hutan produksi Subanjeriji, Kecamatan Gunung Megang, Kabupaten Muara Enim, Sumatera Selatan. Hasil penelitian ini diharapkan dapat dijadikan dasar untuk pengembangan budi daya lebah madu ke depannya.

\section{METODE PENELITIAN}

\section{A. Lokasi dan Waktu}

Penelitian ini dilaksanakan di lokasi budi daya lebah madu KTH Sari Puspa dan terdiri atas 3 lokasi yang berbeda, yaitu Desa Aur Duri (desa di dalam kawasan hutan), Desa Sumaja Makmur (desa yang berbatasan langsung dengan kawasan hutan), dan Desa Bangun Sari (desa yang berada di luar kawasan) Hutan Produksi (HP) Subanjeriji di Kabupaten Muara Enim, Sumatera Selatan. Peta lokasi penelitian disajikan pada Gambar 1. Penelitian dilaksanakan pada bulan November 2019 sampai dengan bulan Maret 2020.

\section{B. Metode Pengambilan Data dan Analisis Data}

Penelitian menggunakan metode survei dengan pendekatan kualitatif dan kuantitatif. Pengumpulan sampel lebah dilakukan pada 3 desa yang dijadikan lokasi budi daya lebah madu dengan cara mengunjungi stup/kotak penangkaran di tiap lokasi penelitian. Sampel lebah pada setiap stup diambil dengan cara meletakkan kantong plastik bening tepat di pintu stup kemudian mengetuknya hingga lebah terbang keluar. Jika sampel individu sudah masuk, maka plastik ditutup dan ditambahkan alkohol 70\%. Sampel kemudian diberi label dan dibawa ke laboratorium untuk diidentifikasi. Pengamatan dan pengukuran morfologi lebah madu dilakukan untuk setiap sampel dan dianalisis secara deskriptif. Penentuan jenis lebah yang diidentifikasi dilakukan dengan menggunakan kunci determinasi yang dikemukakan oleh Engel et al. (2018).

Pengumpulan data jenis tanaman potensial yang dijadikan sumber pakan lebah dilakukan dengan cara observasi langsung pada 3 desa yang dijadikan lokasi budi daya lebah madu. Pada masing-masing lokasi dibuat transek sejauh 100 meter dari lokasi stup. Tanaman yang menurut referensi pustaka potensial menjadi tanaman pakan lebah dicatat yang meliputi informasi jenis dan jumlah tanaman.

Analisis tingkat partisipasi masyarakat, khususnya pembudi daya lebah, dalam pelestarian hutan dilakukan menggunakan metode wawancara dan pengisian kuosioner. Narasumber yang dijadikan sasaran adalah pembudi daya lebah madu yang tergabung dalam KTH Sari Puspa yang berjumlah 20 pembudi daya dan tersebar pada 3 desa lokasi penelitian. Informasi yang digali dari para narasumber adalah sikap dan persepsi dalam budi daya lebah dan pelestarian lingkungan, 


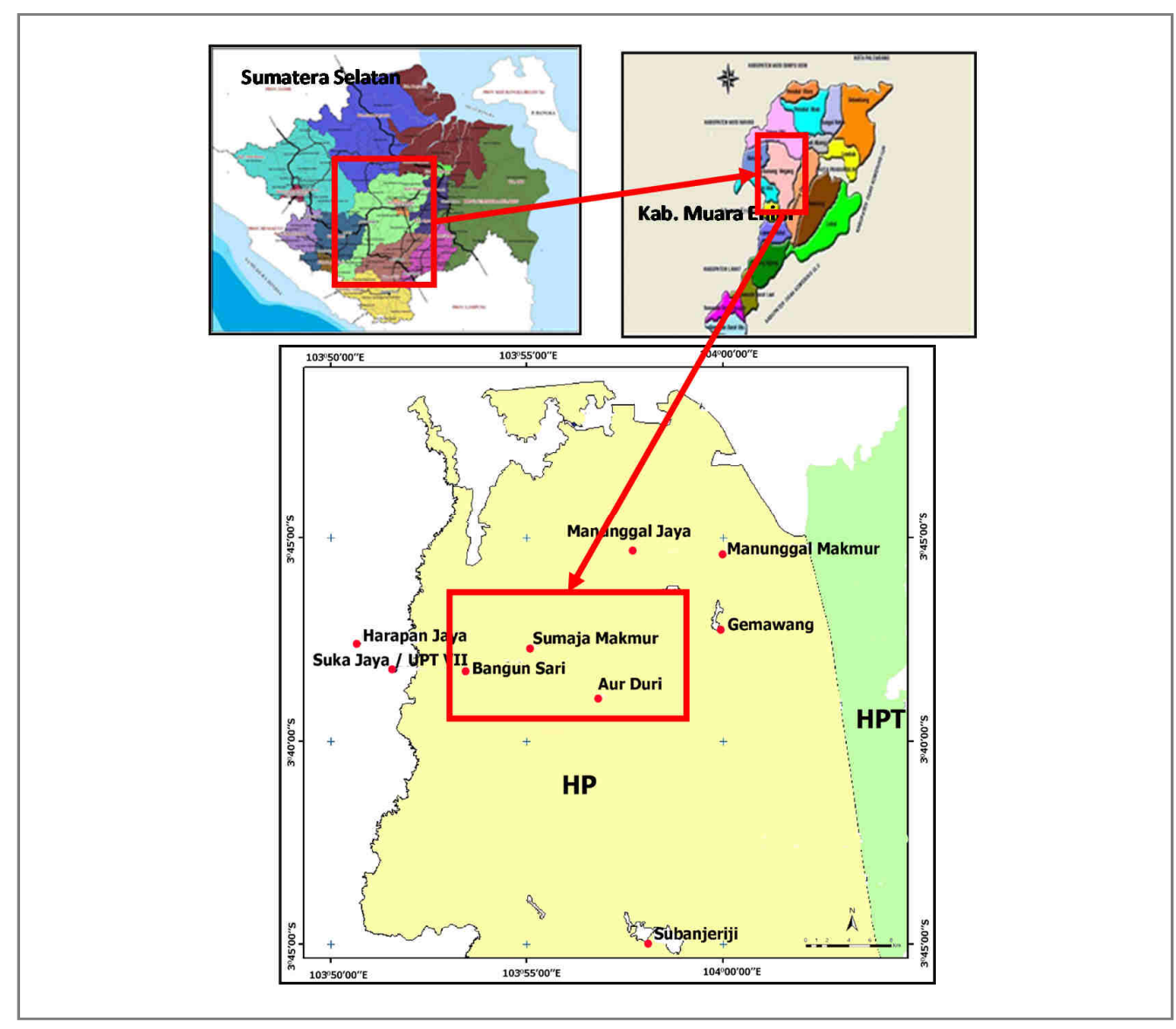

Gambar 1. Peta lokasi penelitian

Figure 1. Map of the study area

seperti pilihan teknik dalam pembukaan atau pembersihan lahan, dampak degradasi hutan terhadap berkurangnya produktivitas madu. Informasi lainnya adalah tentang usaha setiap pembudi daya untuk melakukan penanaman tanaman sebagai bagian dari kegiatan pengayaan kawasan. Analisis data hasil wawancara bertujuan untuk mengetahui persepsi dan sikap pembudi daya lebah madu terkait keberadaan hutan terhadap pengembangan usaha budi daya lebah madu. Analisis data menggunakan metode skor dengan skala Likert (Ramdani et al., 2014). Skala Likert digunakan untuk mengukur sikap, pendapat dan persepsi seseorang atau sekelompok tentang kejadian atau gejala sosial. Dengan demikian, skor ideal untuk mengetahui seberapa besar pemahaman, persepsi dan sikap anggota KTH Sari Puspa terkait keberadaan kawasan terhadap usaha budi daya lebah madu dapat ditentukan. Hasil dari perhitungan skor kemudian dilakukan analisis secara deskriptif untuk menggambarkan persepsi, sikap dan partisipasi pembudi daya terhadap keberadaan hutan bagi keberlangsungan usaha budi daya lebah madu dan usaha-usaha yang dilakukan dalam meningkatkan daya dukung kawasan hutan terhadap usaha budi daya lebah madu. 


\section{HASIL DAN PEMBAHASAN}

\section{A. Jenis Lebah Madu yang Dibudidayakan}

Lebah madu yang berhasil diidentifikasi pada lokasi budi daya lebah madu terdiri dari lebah bersengat yaitu jenis Apis cerana dan lebah tanpa sengat dari genus Trigona. Adapun jenis dan populasi lebah madu yang dibudidayakan disajikan pada Tabel 1 .

Tabel 1. Jenis lebah madu yang dibudidayakan pembudi daya

Table 1. Cultivated types of honey bees cultivators

\begin{tabular}{cclc}
\hline $\begin{array}{c}\text { No } \\
(\text { No. })\end{array}$ & $\begin{array}{c}\text { Lokasi Budi Daya Lebah Madu } \\
\text { (Location of Beekeeping) }\end{array}$ & \multicolumn{1}{c}{$\begin{array}{c}\text { Jenis Lebah Madu } \\
\text { (Beehoney types) }\end{array}$} & $\begin{array}{c}\text { Jumlah Stup/kotak } \\
\text { (Amount of beeboxes) }\end{array}$ \\
\hline 1. & Desa Aur Duri & Apis cerana & 280 \\
& & Tetragonula laeviceps & 50 \\
\cline { 2 - 4 } & & Jumlah Stup & 330 \\
\hline 2. & Desa Sumaja Makmur & Apis cerana & 70 \\
& & Geniotrigona thoracica & 70 \\
& & Heterotrigona itama & 30 \\
& & Lepidorigona terminata & 25 \\
& & Tetrigona apicalis & 10 \\
& & Tetragonula laeviceps & 25 \\
& & Tetragonula testaceitarsis & 10 \\
\cline { 2 - 4 } & & Jumlah stup & 240 \\
\hline 3. & Desa Bangun Sari & Apis cerana & 45 \\
& & Tetragonula laeviceps & 15 \\
& & Heterotrigona itama & 10 \\
& & Lepidorigona terminata & 13 \\
\cline { 2 - 4 } & & Jumlah Stup & 83 \\
\hline
\end{tabular}

Berdasarkan Tabel 1 jumlah koloni lebah madu terbanyak ada di Desa Aur Duri dan paling sedikit ada di Desa Bangun Sari. Jenis Apis cerana dijumpai di ketiga lokasi, dengan jumlah stup terbanyak berada di Desa Aur Duri. Menurut Sihombing (2005) koloni Apis cerana biasanya terdiri dari 20.000-24.000 lebah pekerja, beberapa ratus lebah jantan dan seekor ratu. Stup Apis cerana pada tiap pembudi daya berisi satu koloni lebah yang terdiri atas ratu, lebah jantan dan lebah pekerja. Jenis lebah madu kelulut banyak dibudidayakan oleh pembudi daya di desa Sumaja Makmur. Para pembudi daya beralasan jenis kelulut merupakan jenis lebah tidak bersengat dan cocok dibudidayakan pada area perkebunan karet yang diperkaya dengan tanaman sumber bunga lainnya. Berdasarkan informasi pembudi daya, preferensi dalam memilih jenis lebah madu kelulut yang dibudidayakan juga dilandasi ketersediaan koloni bibit di alam. Lebah kelulut biasanya didapatkan dari hasil mengumpulkan koloni yang sudah terbentuk yang bersarang di batang kayu lapuk, rumah penduduk, bambu dan tempat-tempat lain yang biasa dijadikan koloni lebah kelulut bersarang. Hal ini berbeda dengan Apis cerana yang bisa didapatkan dengan cara "memancing" lewat glodokan.

Jumlah stup jenis Apis cerana di Desa Aur Duri yang cukup banyak sangat 
berhubungan dengan keberadaan akasia (Acacia mangium) yang ditanam di Hutan Produksi Subanjeriji. Hal ini menjadi faktor paling berpengaruh terhadap pemilihan jenis lebah madu yang dibudidayakan di Desa Aur Duri. Lokasi desa yang berada di dalam kawasan hutan menjadikan jarak antara lokasi budi daya dengan tanaman sumber pakan juga menjadi dekat. Menurut Kuntadi (2012) Acacia mangium merupakan salah satu tanaman sumber pakan yang menyediakan nektar ekstraflora. Bagian tanaman Acacia mangium yang dikunjungi oleh lebah madu dan dimanfaatkan sebagai sumber pakannya adalah nektar ekstrafloral. Nektar ini disekresi melalui stomata yang terdapat pada pangkal-pangkal daun khususnya daun yang relatif muda. Ekstraflora pada Acacia mangium disekresi sejak tanaman tersebut berusia dini, yaitu sejak awal tanaman tersebut ditanam akan tetapi akan efektif dimanfaatkan oleh lebah setelah tanaman berumur dua bulan. Bagian lain dari tanaman tersebut yang dimanfaatkan oleh lebah adalah tepung sari yang terdapat pada bagian bunga. Ketersediaan tepung sari pada Acacia mangium baru dapat diperoleh pada tanaman setelah mencapai umur dua tahun ke atas. Musim bunga raya Acacia mangium adalah pada periode bulan Juni sampai dengan Oktober (Kuntadi, 2012). Morfologi lebah Apis cerana yang ditemukan disajikan pada Gambar 2.

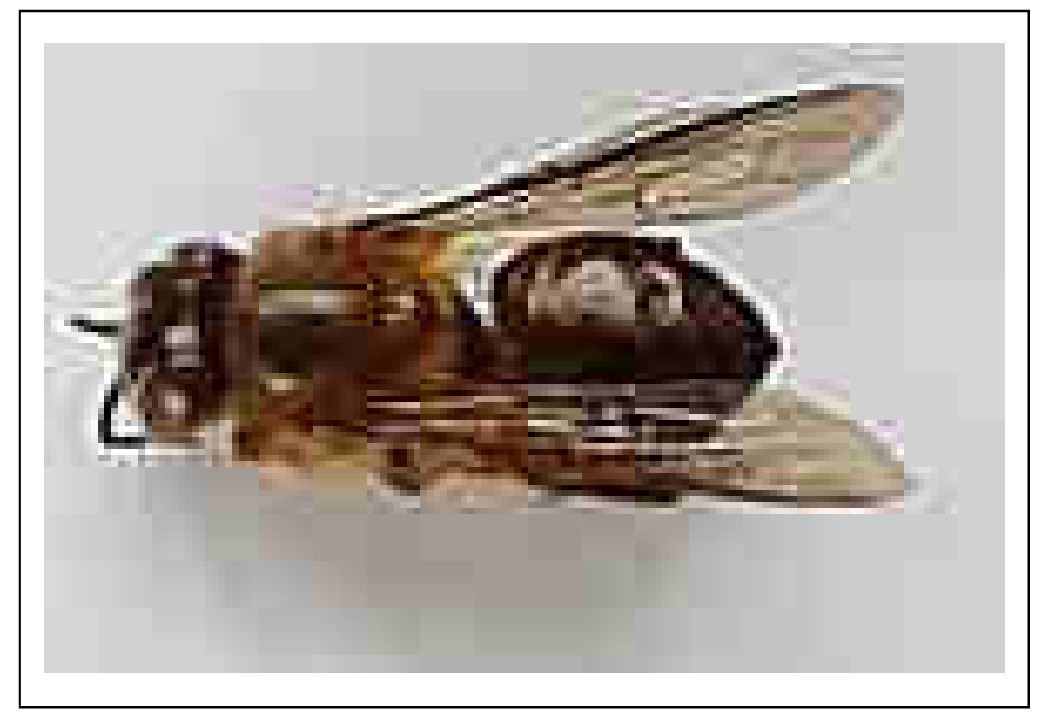

Gambar 2. Morfologi lebah madu Apis cerana pada lokasi penelitian Figure 2. Morfology of honey bee Apis cerana at research location

Jenis lebah kelulut yang dibudidayakan dan paling banyak ditemukan di Desa Sumaja Makmur, yakni 6 jenis kelulut (Gambar 3) dan didominsi dari jenis Geniotrigona thoracica. Jenis kelulut Geniotrigona thoracicadapat diidentifikasi sebagai kelulut berwarna keemasan dengan kaki berwarna hitam dan ujung sayap memudar (Engel et al., 2018).
Pembudi daya banyak membudidayakan jenis Geniotrigona thoracica karena ukurannya yang cukup besar dan hasil madu yang relatif banyak. Kelulut lain yang cukup banyak dibudidayakan adalah jenis Heterotrigona itama. Lebah kelulut ini mirip dengan lalat berwarna hitam dan memiliki ciri khas pada corong keluar masuk sarang yang berbentuk 
belalai gajah atau terompet (Engel et al., 2018). Jenis kelulut Tetragonula laeviceps merupakan jenis yang dibudidayakan di setiap desa lokasi penelitian. Meskipun berukuran paling kecil dan produksi madu relatif sedikit, namun karena kelimpahannya yang sangat banyak di sekitar hutan produksi Subanjeriji menjadikan kelulut jenis ini sebagai kelulut yang mudah didapat dan dibudidayakan. Jenis kelulut lain yang dibudidayakan yaitu Lepidotrigona terminata. Jenis ini dapat diidentifikasi sebagai kelulut kuning cerah dengan bagian belakang hitam berpadu dengan garis kuning di bagian tepi (Engel et al., 2018).

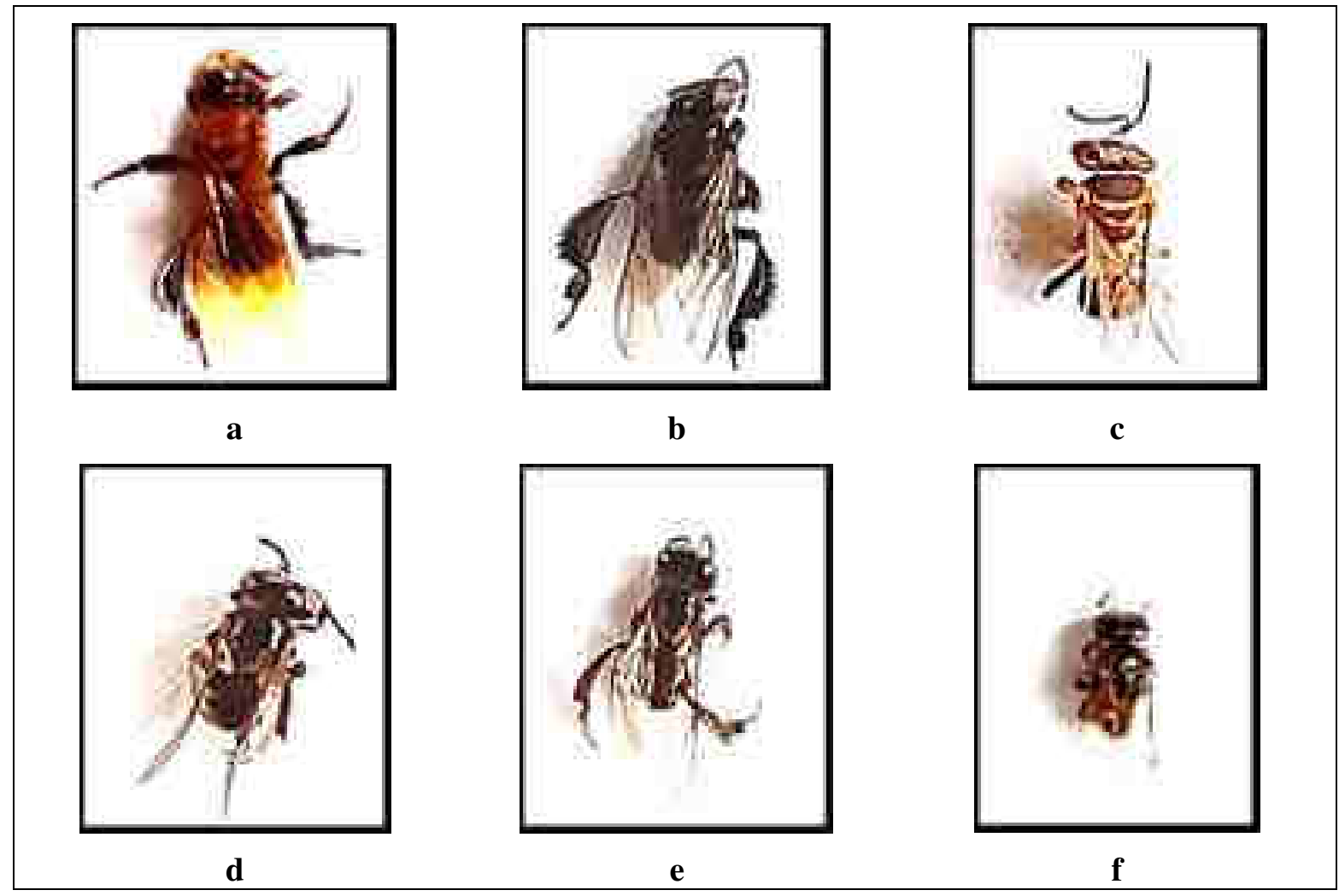

Gambar 3. Morfologi lebah madu Kelulut (Trigona spp.) pada lokasi penelitian, Genitrigona thoracica (a), Heterotrigona itama (b), Tetrigona apicalis (c), Lepidotrigona terminate (d), Tetragonula testaceitarsis (e), dan Tetragonula laeviceps (f).

Figure 3. Morfology of stingless bee Kelulut (Trigona spp) in research location, Genitrigona thoracica (a), Heterotrigona itama (b), Tetrigona apicalis (c), Lepidotrigona terminate (d), Tetragonula testaceitarsis (e), and Tetragonula laeviceps (f).

Kelulut jenis ini juga menjadi primadona bagi pembudi daya lebah madu, karena ukuran yang tidak terlalu kecil, produksi madu cukup banyak dan rasa madu yang lebih disenangi oleh pembeli. Minat pembudi daya dalam budidaya lebah tanpa sangat meningkat pesat setelah adanya informasi bahwa kelulut dapat menghasilkan propolis lebih banyak dibandingkan dengan lebah bersengat (Haryanto et al., 2012). Propolis memiliki berbagai macam manfaat kesehatan seperti mengandung antioksidan dan fenol yang tinggi. Propolis berpotensi untuk menyembuhkan berbagai macam penyakit seperti sakit gigi, influenza, diabetes mellitus, tuberkolosis, dan lain- 
lain (Agustina, 2007).

Berdasarkan hasil identifikasi, selain perbedaan morfologi, kelulut yang dibudidayakan juga memiliki perbedaan pada ukuran tubuh, bentuk sarang dan bentuk corong keluar-masuk pada sarang. Perbandingan ukuran lebah madu yang dibudidayakan oleh pembudi daya pada lokasi penelitian disajikan pada Gambar 4.

Roubik (2006) menyatakan sarang Trigona spp memiliki bentuk pintu masuk yang beragam, seperti berbentuk corong, bulat tidak beraturan atau tanpa tonjolan (corong) pada pintu masuknya. Kelulut Tetragonula testaceitarsis, sering disebut juga kelulut matahari, karena memiliki corong keluar-masuk seperti matahari (Sanjaya et al., 2019). Corong keluar-masuk pada sarang kelulut Tetragonula laeviceps hanya berupa lubang yang dilapisi resin agar hewan lain tidak dapat masuk ke dalam sarang. Menurut Syafrizal et al. (2012), bahan dasar penyusun sarang juga berbeda-beda pada tiap jenis lebah Trigona spp. dengan bentuk warna dan aroma yang dipengaruhi oleh jenis tumbuhan sumber resinnya. Bentuk-bentuk corong keluar masuk sarang lebah kelulut dapat dilihat pada Gambar 5.

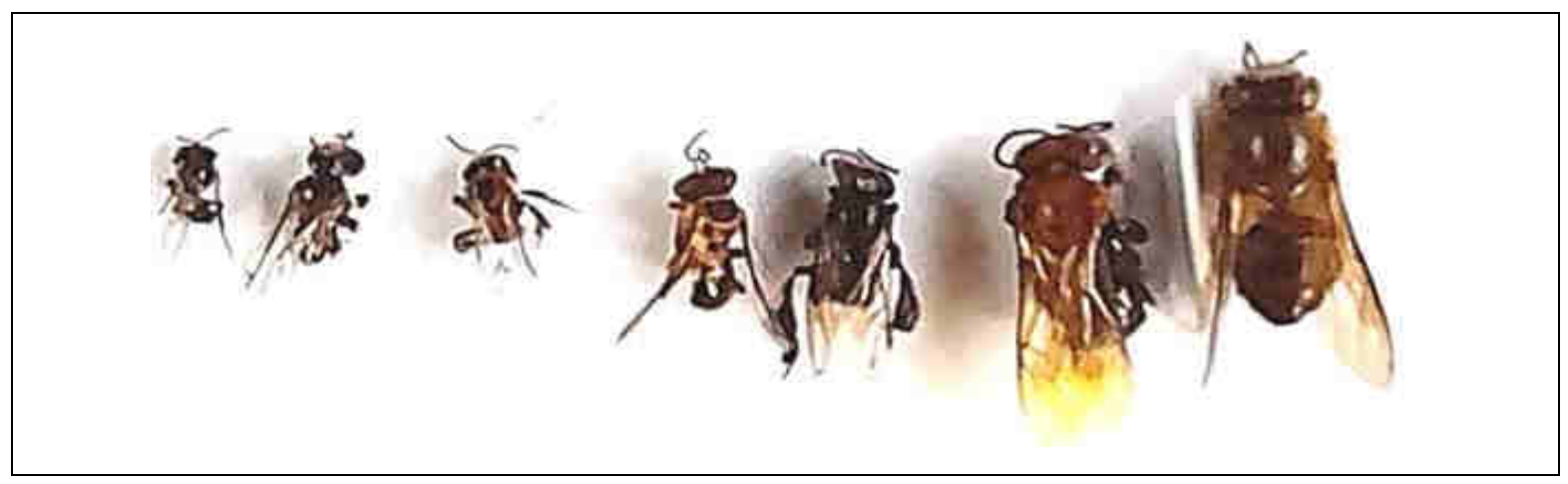

Gambar 4. Perbandingan ukuran lebah madu yang dibudidayakan pada lokasi penelitian Figure 4. Comparison of the size of the honey bees at the research location

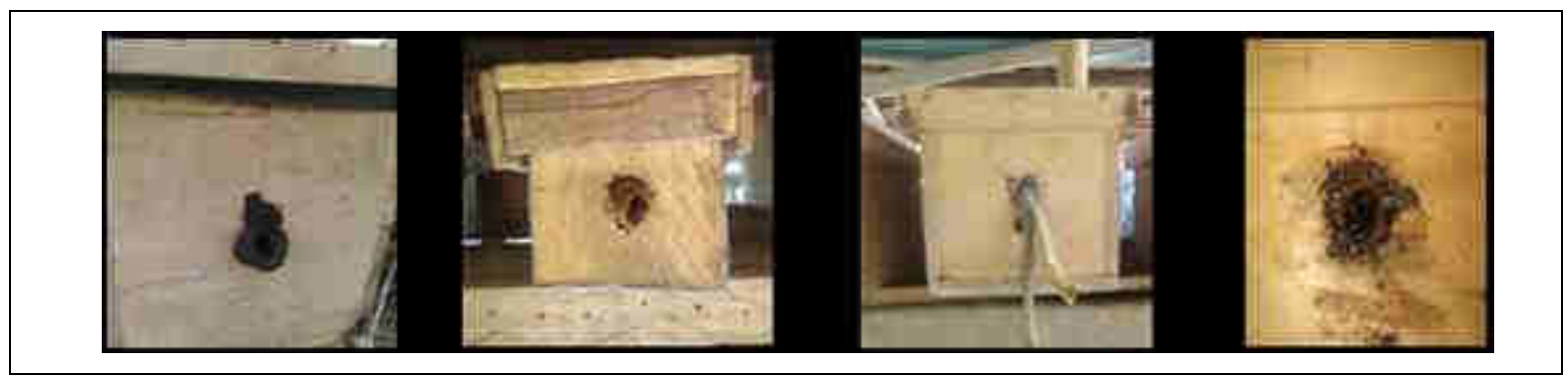

\section{Gambar 5. Bentuk-bentuk corong keluar-masuk sarang lebah kelulut Figure 5. The shape of the hole in and out of the honeycomb}

Berdasarkan hasil pengamatan, jumlah species dan sebaran populasi yang merata di Desa Sumaja Makmur didukung oleh minat pembudi daya yang cukup besar baik dalam hal perbanyakan koloni maupun dalam kegitan perbanyakan atau pengayaan tanaman pakan lebah madu. Kondisi ini menunjukkan bahwa ketersediaan pakan yang cukup dan sangat 
beragam akan mendukung perkembangan koloni dan produktivitas madu. Hal ini sejalan dengan hasil penelitian Pasaribu et al. (2017) yang melaporkan bahwa terdapat hubungan tingkat perkembangan populasi lebah dengan ketersedian nektar pada suatu tanaman yang ditanam oleh petani atau sistem integrasi yang diterapkan.

\section{B. Jenis Tanaman Pakan Lebah Madu}

Jenis tanaman pakan lebah madu pada tiga lokasi budi daya lebah madu mempunyai tingkat keragaman yang berbeda baik dari jenis maupun populasi tanaman. Pemilihan jenis tanaman sumber pakan lebah madu didasarkan pada pemenuhan unsur nektar dan polen bagi lebah madu. Mayoritas pembudi daya memilih menanam tanaman penghasil nektar lebih banyak dibanding penghasil polen, hal ini bertujuan untuk meningkatkan produksi madu. Pembudi daya juga memilih tanaman yang bergetah khusus untuk lebah madu kelulut yang biasanya dimanfaatkan oleh kelulut sebagai bahan campuran membuat sarang dan corong pintu keluar-masuk.

Data hasil identifikasi jenis tanaman beserta jumlah individu tiap spesies ditampilkan pada Tabel 2.

Jumlah spesies tumbuhan yang ditemukan di masing-masing desa adalah empat jenis di Desa Aur Duri, 14 jenis di Desa Sumaja makmur, dan 10 jenis di Desa Bangun Sari. Keragaman jenis tanaman yang ditemukan pada setiap desa berbeda, sesuai dengan peruntukan lahan. Di Desa Aur Duri, lokasi budi daya berada di dalam kawasan hutan, tanaman sumber pakan di dominasi oleh jenis Acacia mangium yang merupakan tanaman utama IUPHTI PT. MHP. Tanaman akasia dapat mengeluarkan titisan nektar di dekat tangkai pangkal daun dan hampir semua pangkal daun akasia mengeluarkan nektar sepanjang tahun sehingga dapat menjadi sumber nektar yang sangat potensial dan berkelanjutan bagi lebah.
Adgaba et al., (2016) menyatakan nektar dari tanaman akasia merupakan nektar yang potensial sebagai sumber pakan lebah madu di Arab Saudi. Produksi madu dari beberapa spesies tanaman akasia juga berbeda-beda, yaitu Acacia asak $110 \mathrm{~kg} / \mathrm{ha}$; Acacia ehrenbergiana $443 \mathrm{~kg} / \mathrm{ha}$; Acacia etbaica $51 \mathrm{~kg} / \mathrm{ha}$; Acacia gerrardii $511 \mathrm{~kg} / \mathrm{ha}$; Acacia johnwoodii 625 $\mathrm{kg} / \mathrm{ha}$; Acacia aoefota $120 \mathrm{~kg} / \mathrm{ha}$; Acacia origena $325 \mathrm{~kg} / \mathrm{ha}$; Acacia tortilis $223 \mathrm{~kg} / \mathrm{ha}$. Jenis tanaman lainnya sebagai sumber pakan di Desa Aur Duri adalah jenis senduduk. Senduduk merupakan jenis tanaman semak yang bunganya dimanfaatkan oleh lebah sebagai sumber nektar. Mengantisipasi lebah kekurangan pakan pada saat musim tebang akasia, pembudi daya di Desa Aur Duri menanam tanaman jenis santostemon dan kaliandra.

Tanaman sumber pakan di Desa Sumaja makmur lebih banyak dan lebih variatif dibanding dua desa lainnya. Hal ini berhubungan dengan lokasi budi daya lebah madu di desa tersebut yang berbatasan lansung dengan kawasan hutan dan berada pada areal perkebunan masyarakat. Pembudi daya meletakkan stup pada areal perkebunan karet dan sawit yang juga telah diperkaya dengan tanaman jenis MPTS yang menghasilkan buah dan beberapa tanaman kehutanan yang berbunga. Jumlah spesies tumbuhan yang banyak di Desa Sumaja Makmur tidak terlepas dari usaha dan peran serta pembudi daya lebah melakukan pengayaan lahan dengan tanaman Multi Purpose Tree Species (MPTS). Tanaman MPTS ditanam dengan orientasi untuk mendapatkan buah dan daun yang bernilai ekonomis dan dapat dikonsumsi, selain sebagai sumber pakan lebah. Pembudi daya di Desa Aur Duri lebih mengandalkan tanaman akasia yang ditanam oleh PT. MHP yang berumur tiga tahun ke atas, sehingga tidak memungkinkan untuk ditanam tumbuhan jenis lainnya karena pengaruh kerapatan tajuk dan lahan yang izin konsensinya dimiliki oleh PT. MHP. 
Tabel 2. Jenis tanaman sumber pakan lebah madu Table 2. Woof source plant types of honeybees

\begin{tabular}{|c|c|c|c|}
\hline \multirow[t]{2}{*}{$\begin{array}{c}\text { Desa } \\
\text { (Village })\end{array}$} & \multicolumn{2}{|c|}{$\begin{array}{l}\text { Jenis Tanaman } \\
\text { (Plant species) }\end{array}$} & \multirow[t]{2}{*}{$\begin{array}{c}\text { Jumlah of transek } \\
\text { (Amount of transect) }\end{array}$} \\
\hline & $\begin{array}{c}\text { Nama Ilmiah } \\
\text { (Scientific name) }\end{array}$ & $\begin{array}{l}\text { Nama Lokal } \\
\text { (Local name) }\end{array}$ & \\
\hline \multirow[t]{4}{*}{ Aur Duri } & Acacia mangium & Akasia & 40 \\
\hline & Melastoma malabathricum & Senduduk & 18 \\
\hline & Xanthostemon chrysanthus & Santostemon & 8 \\
\hline & Calliandra calothyrsus & Kaliandra & 14 \\
\hline \multirow[t]{14}{*}{ Sumaja Makmur } & Manilkara kauki & Sawo & 2 \\
\hline & Mangifera indica & Mangga & 2 \\
\hline & Artocarpus heterophyllus & Nangka & 1 \\
\hline & Anacardium occidentale & Jambu Monyet & 1 \\
\hline & Citrus aurantifolia & Jeruk & 15 \\
\hline & Musa sp & Pisang & 2 \\
\hline & Albizzia falcataria & Albasia & 6 \\
\hline & Solanum torvum & Cempokak & 2 \\
\hline & Jatropha multifida & Yodium & 2 \\
\hline & Cocos Nucifera & Kelapa & 4 \\
\hline & Elaeis guineensis & Sawit & 20 \\
\hline & Dimocarpus longan & Kelengkeng & 1 \\
\hline & Psidium guajava & Jambu biji & 2 \\
\hline & Syzygium aqueum & Jambu air & 1 \\
\hline \multirow[t]{10}{*}{ Bangun Sari } & Nephelium lappaceum & Rambutan & 4 \\
\hline & Antigonon & Air mata pengantin & 2 \\
\hline & Manilkara kauki & Sawo & 2 \\
\hline & Tagetes erecta & Gemitir & 2 \\
\hline & Citrus maxima & Jeruk bali & 2 \\
\hline & Helianthus annuиs & Bunga matahari & 10 \\
\hline & Calliandra calothyrsus & Kaliandra & 22 \\
\hline & Delonix regia & Flamboyan & 2 \\
\hline & Hevea brasiliensis & Karet & 30 \\
\hline & Passiflora edullis & Markisa & 4 \\
\hline
\end{tabular}

Jenis tanaman pada tiga desa lokasi penelitian juga berbeda pada jumlah tanaman pokok yang tersedia dalam jumlah banyak, seperti akasia, tanaman karet dan tanaman sawit. Hasil penelitian Mulyono et al., (2015), mengenai Kajian Ketersediaan Pakan Lebah Madu Lokal (Apis cerana Fabr.) di
PUSBAHNAS (Pusat Perlebahan Nasional) Parung Panjang, Bogor menyimpulkan bahwa tanaman akasia merupakan tanaman yang paling sering dikunjungi lebah sebagai tanaman penghasil nektar ekstra floral, tanaman kelapa sawit sebagai tanaman penghasil polen dan tanaman karet sebagai tanaman penghasil nektar 
dengan intensitas kunjungan lebah yang lebih rendah. Penelitian lebih lanjut diperlukan terutama yang berhubungan dengan volume nektar dan berat polen setiap tanaman, sehingga dapat memprediksi volume nektar yang dihasilkan dan berat polen setiap tangkai bunga, satu karangan bunga, satu pohon dan bahkan setiap satuan luas tanam.

Informasi keragaman tanaman sumber pakan lebah mempunyai peranan yang penting dalam mendukung budi daya lebah madu. Pemilihan tanaman yang mampu menyediakan nektar sepanjang tahun akan mendukung usaha peningkatan produktifitas lebah madu. Produksi nektar dari jenis tanaman berbeda-beda setiap waktu (Roubik, 2006). Semakin tinggi keragaman jenis tanaman sumber pakan lebah madu memungkinkan tersedianya nektar dan polen sepanjang tahun.

\section{Partisipasi Masyarakat dalam Usaha Pelestarian Hutan}

Hasil analisis persepsi pembudi daya lebah madu terhadap urgensi kebeadaan kawasan hutan bagi usaha budi daya lebah madu disajikan pada Tabel 3.

Tabel 3. Persepsi pembudi daya lebah madu terhadap urgensi keberadaan kawasan hutan bagi usaha budi daya lebah madu

Table 3. The perception of beekeepers on the urgency of the forest sustainability for beekeeping

\begin{tabular}{clcc}
\hline $\begin{array}{c}\text { No } \\
\text { (No.) }\end{array}$ & \multicolumn{1}{c}{$\begin{array}{c}\text { Tolak Ukur } \\
\text { (Indicators) }\end{array}$} & $\begin{array}{c}\text { Jumlah } \\
\text { Responden } \\
\text { (Respondances) }\end{array}$ & $\begin{array}{c}\text { Skor (\%) } \\
\text { (Score } \\
\text { (\%) })\end{array}$ \\
\hline 1. & $\begin{array}{l}\text { Keberadaan kawasan hutan sangat memengaruhi } \\
\text { keberhasilan budi daya lebah madu }\end{array}$ & 20 & 80 \\
2. & $\begin{array}{l}\text { Sangat memahami kebakaran hutan dan lahan dapat } \\
\text { mengurangi populasi lebah dan mengurangi jumlah hasil } \\
\text { panen madu }\end{array}$ & 20 & 60 \\
3. & $\begin{array}{l}\text { Sangat setuju tegakan tanaman dalam kawasan hutan } \\
\text { sangat memengaruhi produksi madu } \\
\text { Selalu melakukan pengayaan lahan melalui penanaman } \\
\text { tanaman berkayu sebagai sumber pakan lebah madu } \\
\text { Jenis tanaman yang paling banyak di tanam sebagai sumber } \\
\text { pakan lebah adalah jenis tanaman MPTS }\end{array}$ & 20 & 98 \\
\hline
\end{tabular}

Hasil analisis menunjukkan bahwa persepsi pembudi daya lebah madu terhadap urgensi keberadaan kawasan hutan bagi usaha budidaya lebah madu sangat baik. Berdasarkan data pada Tabel 3 , sebanyak $80 \%$ pembudi daya setuju bahwa keberadaan kawasan hutan sangat memengaruhi keberhasilan budi daya lebah madu. Oleh sebab itu para pembudi daya sepakat bahwa degradasi kawasan hutan hanya akan merugikan usaha budi daya lebah madu yang mereka kembangkan. Pemahaman bahwa kebakaran hutan dan lahan akan berdampak negatif pada berkurangnya populasi lebah sehingga berdampak pada menurunnya jumlah produksi madu juga cukup tinggi. Hal ini ditunjukkan oleh $60 \%$ pembudi daya yang memahami hubungan kebakaran hutan/lahan dan produksi madu. Sebagian besar pembudi daya berpendapat bahwa ketika membersihkan lahan dengan cara membakar maka akan berdampak pada migrasinya lebah yang dibudidayakan di dalam stup. Pembudi daya juga mempunyai pengetahuan bahwa pada sebagian gulma yang tumbuh terdapat beberapa 
jenis gulma yang sering dikunjungi oleh lebah untuk mencari nektar dan polen. Oleh sebab itu pembakaran untuk membuka lahan lebih dihindari. Keberadaan tanaman di dalam kawasan hutan juga memengaruhi produksi madu. Hal ini didukung oleh sikap 85\% pembudi daya yang sangat setuju dengan hal tersebut, sehingga $98 \%$ pembudi daya melakukan pengayaan lahan dengan jenis tanaman berkayu maupun MPTS. Sebanyak $80 \%$ pembudi daya memilih jenis tanaman MPTS penghasil buah-buahan sebagai pilihan utama dalam pengayaan lahan.

Pembudi daya di tiga desa juga aktif dalam upaya pengayaan lahan dengan menanam tanaman jenis lain selain tanaman pokok berupa tanaman karet dan sawit. Partisipasi aktif pembudi daya anggota KTH Sari Puspa didasari pemahaman bahwa terdapat hubungan yang erat antara keberadaan tanaman sumber pakan dengan peningkatan produktivitas lebah. Pembudi daya juga memahami bahwa ketersediaan tanaman harus mampu mencukupi pakan lebah sepanjang tahun. Lebah dan tanaman memiliki ketergantungan yang saling menguntungkan. Lebah dapat membantu tanaman dalam melakukan penyerbukan tanpa merusak organ-organ yang terdapat pada tanaman. Tanaman memberikan pakan yang dibutuhkan oleh lebah berupa nektar dan polen. Di daerah tropis seperti Indonesia, lebah dapat berkembang biak dengan baik dan produktif sepanjang tahun karena ketersediaan sumber pakan yang berkelanjutan. Keberadaan lebah didukung dengan adanya sumber pakan yang tersedia (Yunianto dan Jannetta, 2020).

Bentuk partisipasi aktif pembudi daya anggota KTH Sari Puspa dalam usaha pelestarian hutan juga berupa penyediaan lahan seluas \pm 4 hektar sebagai lahan biodiversitas tanaman sumber pakan yang didukung oleh program Coorporate Social Responsibility
(CSR) PT. MEDCO E\&P Indonesia (Gambar 6). Pada lahan ini ditanami jenis tanaman yang terdiri atas tanaman kehutanan, tanaman perkebunan, dan tanaman hias sebagai sumber pakan lebah. KTH Sari Puspa juga aktif dalam mengajukan bantuan bibit dari instansi terkait seperti bantuan bibit tanaman kaliandra dan tanaman akasia jenis Acacia crassicarpa. Tanaman yang berasal dari bantuan dan hibah tersebut ditanam pada lahan yang dijadikan lokasi budidaya lebah madu. Jenis kegiatan untuk pembudi daya yang berada di dalam kawasan hutan berbeda. Lahan yang berasal dari okupasi kawasan hutan yang semula ditanam dengan tanaman jenis karet dan sawit diganti dengan tanaman jenis akasia.

Hasil pengamatan juga menemukan kondisi di mana beberapa pembudi daya telah mulai mengembangkan dan menggunakan pestisida nabati yang lebih ramah lingkungan. Hal ini sejalan dengan pengetahuan para pembudi daya bahwa dampak negatif dari pestisida selain menyebabkan gangguan kesehatan juga dapat mencemari lingkungan. Khusus bagi pembudi daya lebah madu, mereka juga mengetahui bahwa beberapa jenis lebah tidak resisten terhadap pestisida dan mempunyai kemungkinan dapat mencemari madu yang dihasilkan. Persepsi, sikap dan pengetahuan yang cukup baik yang dimiliki pembudi daya lebah madu, dapat dijadikan sebagai modal dasar pengembangan budi daya lebah madu ke arah yang lebih baik lagi. Motivasi mengembangkan usaha budi daya lebah madu tidak hanya sebatas orientasi ekonomi, namun juga sebagai bagian dari pelestarian lingkungan dan turut serta dalam menjaga keberlangsungan keberadaan kawasan hutan. Hal ini tidak terlepas dari pengetahuan anggota KTH Sari Puspa bahwa antara hutan, lebah dan pembudi daya terdapat hubungan simbiosis yang saling menguntungkan. 

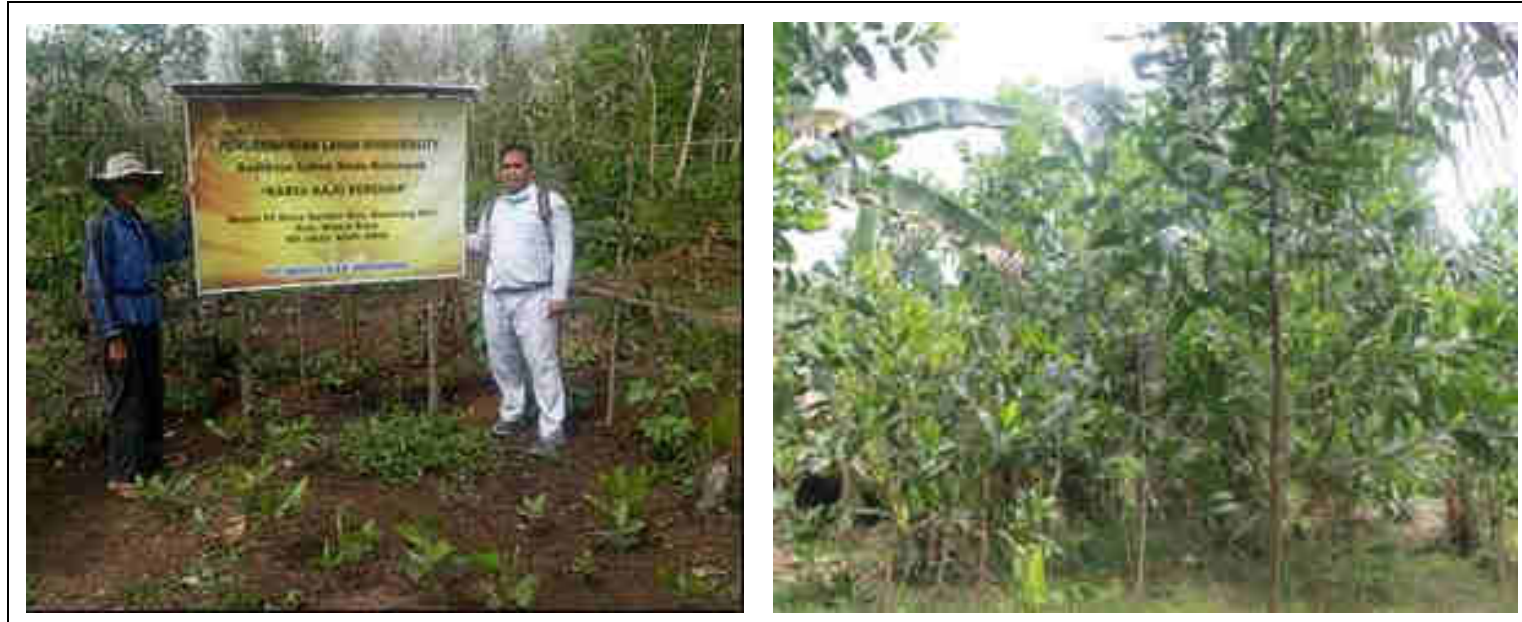

Gambar 6. Pengembangan lahan pakan lebah madu
Figure 6. Woof source land development

\section{KESIMPULAN}

Lebah madu yang dibudidayakan oleh pembudi daya anggota KTH Sari Puspa di Desa Sumaja Makmur, Desa Aur Duri dan Desa Bangun Sari terdiri atas lebah bersengat jenis Apis cerana Fabr. dan lebah tak bersengat jenis Trigona $s p$, dengan variasi sebanyak 6 spesies yakni Genitrigona thoracica), Heterotrigona itama, Tetrigona apicalis, Lepidotrigona terminata, Tetragonula testaceitarsis, dan Tetragonula laeviceps. Jenis tanaman sumber pakan lebah yang berhasil di identifikasi terdiri atas jenis tanaman kehutanan antara lain jenis akasia, albasia, flamboyan dan kaliandra, tanaman MPTS seperti mangga, nangka, dan jambu, tanaman perdu dan semak. Lebih dari 50\% pembudi daya di KTH Sari Puspa memiliki pemahaman bahwa kebakaran hutan dan lahan akan berdampak pada pengurangan populasi lebah yang akan menurunkan jumlah produksi madu. Keberadaan tanaman di dalam kawasan hutan juga memengaruhi produksi madu, oleh sebab itu hampir seluruh pembudi daya melakukan pengayaan lahan dengan jenis dominan berupa jenis MPTS penghasil buahbuahan.

Lebah madu yang diidentifikasi pada penelitian ini berasal dari stup budi daya yang menurut informasi pembudi daya berasal dari kawasan hutan produksi Subanjeriji. Penelitian lebih lanjut perlu dilakukan untuk mengidentifikasi secara langsung lebah madu yang bersarang dan hidup secara bebas pada kawasan hutan Subanjeriji. Penelitian sumber pakan juga perlu mengamati jenis-jenis tanaman yang dikunjungi lebah madu berdasarkan frekuensi dan durasi kunjungan, sehingga didapatkan data jenis sumber pakan berdasarkan tingkat kesukaan dari lebah madu itu sendiri. Penelitian lainnya yang dapat dilakukan adalah menghitung kontribusi usaha budi daya lebah madu terhadap peningkatan pendapatan rumah tangga pembudi daya lebah madu.

Beberapa upaya yang dapat dilakukan dalam rangka pengembangan usaha budidaya lebah madu ke arah yang lebih baik adalah: (1) peningkatan kapasitas (skill) pembudi daya lebah madu dan alih teknologi produksi produk turunan perlebahan lainnya seperti beepollen, 
royal jelly, propolis, sabun lilin lebah dan produk lainnya yang juga bernilai ekonomis tinggi, (2) alokasi lahan pada areal konsesi PT. MHP yang berada di sekitar desa lokasi budi daya lebah madu, khusus ditanami dengan tegakan jenis akasia, sehingga dapat menjadi sumber pakan lebah madu dan menjamin keberlansungan produksi sepanjang tahun, (3) peningkatan jumlah stup budi daya lebah madu dengan diiringi peningkatan jumlah dan jenis tanaman sumber pakan lebah khususnya penyedia nektar, (4) bantuan permodalan, stimulus ekonomi dan hibah dari lembaga, institusi dan perusahaan khususnya dalam peningkatan kualitas produk madu dan pengemasan sehingga mampu bersaing dengan produk madu skala industri, dan (5) pembudi daya yang akan mengembangkan skala usaha budi daya lebah madu maka disarankan memilih jenis lebah Apis cerana untuk lebah bersengat dan jenis Genitrigona thoracica, Heterotrigona itama, Tetrigona apicalis, dan Lepidotrigona terminate untuk jenis lebah kelulut atau tidak bersengat.

\section{UCAPAN TERIMA KASIH}

Ucapan terima kasih kami sampaikan kepada Bapak Suryadin selaku ketua Kelompok Tani Hutan (KTH) Sari Puspa, Bapak Bustam, dan Bapak Darim, yang telah memberikan dukungan selama pelaksanaan penelitian dan pengambilan data.

\section{KONTRIBUSI PENULIS}

Beni Rahmad sebagai kontributor utama. Nurhayati Damiri sebagai analis data dan kontributor pendukung. Mulawarman sebagai analis data dan kontributor pendukung.

\section{DAFTAR PUSTAKA}

Adgaba, N., A. Al-Ghamdi, Y. Tadesse, A.
Getachew, A. M. Awad, M. J. Ansari, A. A. Owayss, S. E. A. Mohammed, \& A. S. Alqarni. (2016). Nectar secretion dynamics and honey production potentials of some major honey plants in Saudi Arabia. Saudi J. Biological Sciences 24: 180-191.

Agussalim, Ali A., Nafiatul U., \& I G Suparta Budisatria. (2017). Variasi jenis tanaman pakan lebah madu sumber nektar dan polen berdasarkan ketinggian tempat di Yogyakarta. Buletin Peternakan Vol. 41 (4): 448-460.

Agustina, I.Q., (2007). Pengaruh pemberian ekstrak propolis terhadap pertumbuhan bakteri Pseudomonas aeruginosa dan Staphylococcus epidermidis (Skripsi). Jurusan Biologi Fakultas Sains dan Teknologi Universitas Islam Negeri Malang, Malang.

Djajasaputra, M. R. (2010). Potensi budi daya lebah Trigona dan pemanfaatan propolis sebagai antibiotik alami untuk sapi PO. Bogor: Institut Pertanian Bogor.

Engel, M.S., Kahono S, \& Peggie D. (2018). A key to the genera and subgenera of stingless bee in Indonesia (Hymenoptera: Apidae). Treubia, 45: 65-86.

Haryanto, B., Hasan, Z., Kuswandi \& Artika,I.M., (2012). Penggunaan propolis untuk meningkatkan produktivitas ternak sapi Peranakan Ongole (PO). JITV Vol. 17 No3, p.202.

Kahono S, \& Erniwati. (2014). Keragaman dan kelimpahan lebah sosial (Apidae) pada bunga tanaman pertanian musiman yang diaplikasi pestisida di Jawa Barat. Berita Biologi, 13(3): 231-238. 
Kuntadi (2012). Pengembangan budi daya lebah madu dan permasalahannya. Pusat Penelitian dan Pengembangan Konsevasi dan Rehabilitasi Badan Penelitian dan Pengembangan Kehutanan, Bogor.

Michener, C. D. (2007). The bees of the world $2^{\text {nd }} e d$. Johns Hopkins University Press, Baltimore.

Mulyono, Tun Susdiyanti, \& Bambang S. (2015). The study of availability of local honey bees feed. Jurnal Nusa Sylva Volume 15 No.2 Desember 2015:18-26.

Novandra, A., \& I. M. Widnyana. (2013). Peluang pasar produk perlebahan Indonesia. Balai Penelitian Teknologi Hasil Hutan Bukan Kayu, Mataram.

Pasaribu R., H. D. Putranto, \& Sutriyono. (2017). Perbandingan produksi lebah madu Apis cerana pada dua sistem integrasi yang berbeda di Kabupaten Rejang Lebong. Jurnal Sain Peternakan Indonesia Vol. 12 No. 4 OktoberDesember 2017: 432-443

Ramdani F., Poltak BP Panjaitan, dan Kustin B. (2014). Persepsi kelompok tani terhadap program pemberdayaan masyarakat budi daya lebah madu Apis mellifera di Tahura Ir. H. Djuanda Bandung. Jurnal Nusa Sylva Vol. 14 No.2. 2014: 33-42.

Roubik, DW. (2006). Stingless Bee Nesting Biology. Apidologie, 37: 124-143.

Roubik, DW. (1991). Aspects of Africanized honey bee ecology in tropical America. In: The African Honey Bee. M. Spivak,
D.J.C. Fletcher and M.D. Breed (Eds.). Westview Press, Boulder. pp. 259-281.

Saepudin R, S. Kadarsih \& R. Sidahuruk. (2017). Pengaruh integrasi lebah dengan palawija terhadap produksi madu di daerah Rejang Lebong, Bengkulu. Jurnal Sain Peternakan Indonesia Vol. 12 No. 1 Januari- Maret 2017:55-63.

Sanjaya, V. Dwi Astiani, \& Lolyta S. (2019). Studi habitat dan sumber pakan lebah kelulut di Kawasan Cagar Alam Gunung Nyiut Desa Pisak Kabupaten Bengkayang. Jurnal Hutan Lestari, Vol. 7 (2) : 786 - 798.

Sihombing, D. T. H. (2005). Ilmu Ternak Lebah Madu. Gadjah Mada University Press. Yogyakarta.

Syafrizal, A. A. Bratawinata, M. Sila, \& D. Marji. (2012). Jenis lebah kelulut (Trigona Spp.) di Hutan Pendidikan Lempake. Mulawarman Scientifie, Volume 11, Nomor 1, April 2012: 11-18.

Syafrizal, Tarigan D, \& Yusuf R. (2014). Keragaman dan habitat lebah trigona pada hutan sekunder tropis basah di Hutan Pendidikan Lempake, Samarinda, Kalimantan Timur. Jurnal Teknologi Pertanian, 9(1), 34-38.

Yunianto, A.S., \& Syasri Jannetta. (2020). Potensi budi daya lebah madu sebagai harapan di tengah pandemi Covid-19. Seminar Nasional Pemberdayaan Masyarakat, Pekanbaru, 19 November 2020. Unri Conference Series: Community Engagement. Volume 2, Riau. 